\title{
Development of Imidazole-Reactive Molecules Leading to a New Aggregation-Induced Emission Fluorophore Based on the Cinnamic Scaffold
}

Vincenzo Razzano, ${ }^{\dagger}$ Marco Paolino, ${ }^{\dagger}$ Annalisa Reale, ${ }^{\dagger}$ Germano Giuliani, ${ }^{\dagger}$ Roberto Artusi, ${ }^{\ddagger}$ Gianfranco Caselli, ${ }^{\ddagger}$ Michela Visintin, ${ }^{\ddagger}$ Francesco Makovec, ${ }^{\ddagger}$ Alessandro Donati, ${ }^{\dagger}$

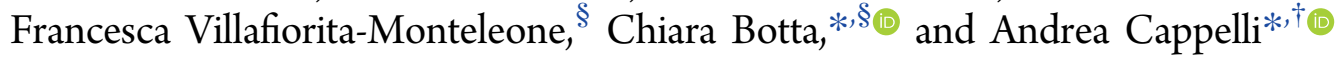

${ }^{\dagger}$ Dipartimento di Biotecnologie, Chimica e Farmacia and European Research Centre for Drug Discovery and Development, Università di Siena, Via A. Moro 2, 53100 Siena, Italy

${ }^{\ddagger}$ Rottapharm Biotech S.p.A., Via Valosa di Sopra 9, 20900 Monza, Italy

${ }^{\S}$ Istituto per lo Studio delle Macromolecole (CNR), Via A. Corti 12, 20133 Milano, Italy

Supporting Information

ABSTRACT: In order to obtain new fluorophores potentially useful in imidazole labeling and subsequent conjugation, a small series of MoritaBaylis-Hillman acetates $(\mathbf{3 a}-\mathbf{c})$ was designed, synthesized, and reacted with imidazole. The optical properties of the corresponding imidazole derivatives $4 a-c$ were analyzed both in solution and in the solid state. Although the solutions display a very weak emission, the powders show a blue emission, particularly enhanced in the case of compound $4 c$ possessing two methoxy groups in the cinnamic scaffold. The photophysical study confirmed the hypothesis that the molecular rigidity of the solid state enhances the emission properties of these compounds by triggering the restriction of intramolecular motions, paving the way for their applications in fluorogenic labeling.
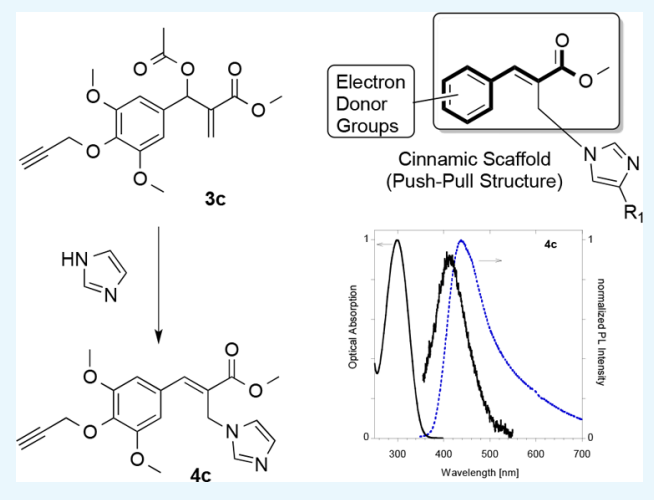

\section{INTRODUCTION}

Imidazole is an aromatic five-membered heterocyclic ring in which the nitrogen atoms are not adjacent and is considered as a fascinating tool in organic chemistry because of its features including high polarity, water solubility, and amphoteric character. ${ }^{1,2}$ Imidazole is contained in many synthetic compounds of pharmaceutical interest including some antifungal, antiprotozoal, antihypertensive, and antileukemic. ${ }^{3,4}$ Moreover, its structure is also frequent in natural compounds such as theophylline, purine, and histamine. Again, imidazole residues are also included in several biological systems owing to their presence in the side chain of the amino acid histidine. ${ }^{5}$ The imidazole ring of histidine is involved in many biological processes such as in the active sites of ribonuclease and serine proteases and in the complexation of metal ions in metalloproteinases such as hemoglobin, myoglobin, and cytochrome $C^{6}$ Thanks to the important presence of imidazole in numerous vital processes, the chemistry developed on imidazole can be used as an important link between the organic chemistry and the biological chemistry. ${ }^{7}$

In biochemistry, proteins are labeled selectively at precisely defined positions in order to study their structure-function behavior. Protein labeling strategies are generally based on the chemical reactivity of particular amino acid side chains containing primary amino or thiol groups. In recent years, a remarkable interest has been devoted to the development of new probes potentially useful in the site-specific tagging of proteins in complex biochemical environments. ${ }^{8-10}$

In particular, the insertion of a hexahistidine sequence at one extremity of a recombinant protein is currently used in the isolation and purification of proteins expressed by bacteria from recombinant DNA vectors. This strategy allows the recombinant protein to be purified from native proteins by affinity chromatography and became the standard technology for the preparation of recombinant proteins. The presence of a hexahistidine tag has been exploited in coordination-chemistry-based protein labeling procedures ${ }^{11,12}$ and provides also an interesting prospect for selective irreversible protein derivatizations. $^{11,13}$

On the other hand, biochemists exploit fluorescence spectroscopy as an analytical technique in the study of protein interactions and functions. The most commonly used detection techniques are based on the use of fluorescent organic dyes, but recently, fluorogenic labeling methods emerged as more promising approaches owing to their higher signal-to-noise ratio, which is caused by the fluorescence activation in the

Received: June 14, 2017

Accepted: August 21, 2017

Published: September 6, 2017 
probe after its reaction/attachment to the desired site. ${ }^{10,14-16}$ Particularly interesting are fluorogens showing emission intensities higher in the solid state than in solution, possessing aggregation-induced emission (AIE) properties. ${ }^{17,18}$ These fluorophores offer higher sensitivity, better accuracy, and improved photostability with respect to traditional fluorescence probes that are generally well-emissive in solution but undergo aggregation-caused quenching processes at high concentration. ${ }^{19,20}$

Alkylation of histidine residues in polyhistidine tags of engineered proteins could be a difficult task because imidazole rings usually show low reactivity in conventional alkylation reactions. Morita-Baylis-Hillman adducts (MBHAs) have been proposed to represent interesting reagents capable of alkylating imidazole by means of a concerted additionelimination process. ${ }^{21}$ Thus, owing to their high reactivity to imidazole in the presence of water, ${ }^{22}$ MBHA derivatives could find applications as reagents for imidazole modification. For example, a successful alkylation of $\mathrm{N}$-acetylhexahistidine with MBHA derivatives was performed by means of the aid of transition-metal cations interacting with a nitrilotriacetate ligand linked to an MBHA leaving group. ${ }^{23}$

In the present paper, MBHA derivatives $3 \mathbf{a}-\mathbf{c}$ (Figure 1) were designed as imidazole-reactive molecules capable of producing imidazole-binding cinnamic derivatives (IBCDs) $4 a-c$.
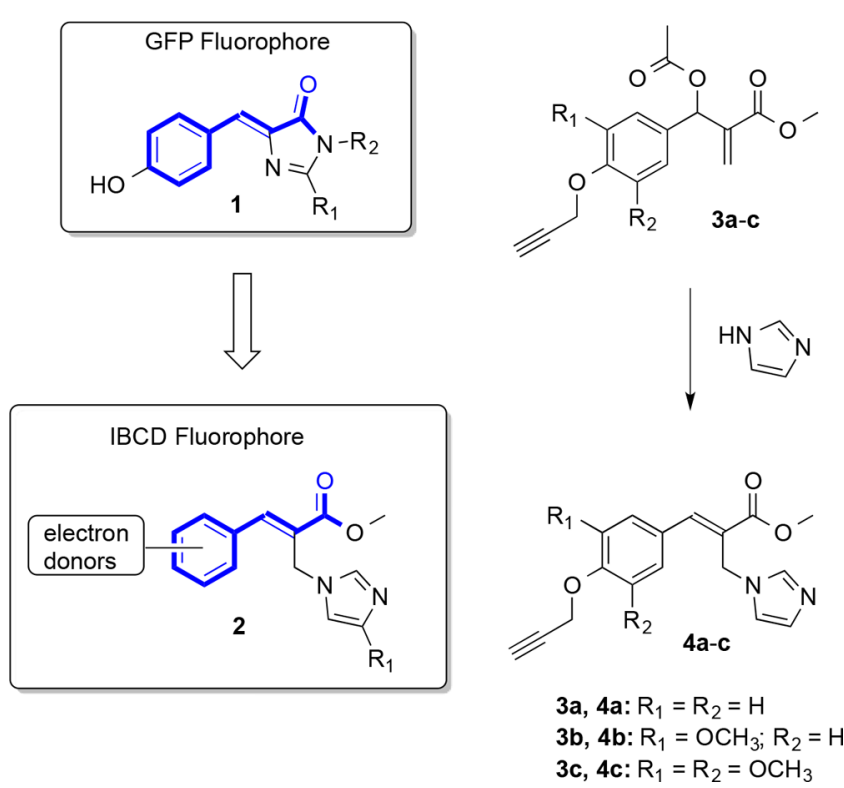

Figure 1. Design of imidazole-reactive molecules $3 \mathbf{a}-\mathbf{c}$ leading to IBCDs $4 a-c$ showing fluorogenic properties. The bold lines highlight the common cinnamic scaffold in the fluorophores.

Interestingly, we envisioned that the important structural elements (i.e., the push-pull structure in blue in Figure 1) of IBCD cinnamic scaffold are contained into the green fluorescent protein (GFP) fluorophore (1), leading to the assumption that compounds $4 \mathbf{a}-\mathbf{c}$ could enhance their emissive features by the RIM (restriction of intramolecular motions) phenomenon, thus showing fluorogenic properties.

Moreover, the introduction of the electron donor methoxy groups in the cinnamic scaffold should increase the push-pull character of the scaffold, altering the emission features of the compounds. $^{24-27}$ Thus, a small series of Morita-Baylis-
Hillman acetates $(3 \mathbf{a}-\mathbf{c})$ was synthesized and made to react with imidazole to obtain the corresponding imidazole derivatives $\mathbf{4 a}-\mathbf{c}$, which were characterized from the point of view of their optical properties.

\section{RESULTS AND DISCUSSION}

MBHA derivatives $3 a-c$ were synthesized by the methodologies described in Scheme 1. In particular, MBHA derivative

Scheme 1. Synthesis of MBHA Derivatives $3 a-c$ and Their Reaction with Imidazole ${ }^{a}$

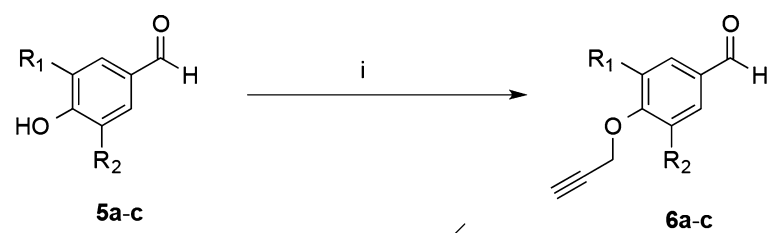

(a) $R_{1}=R_{2}=H$

(b) $\mathrm{R}_{1}=\mathrm{H}, \mathrm{R}_{2}=\mathrm{OCH}_{3}$

(c) $\mathrm{R}_{1}=\mathrm{R}_{2}=\mathrm{OCH}_{3}$

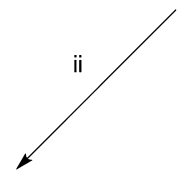

$6 a-c$<smiles>[R2]c1cc(C(O)C(=C)C(=O)OC)cc([R2])c1OCC#CCC#CCCC</smiles>

7a-c

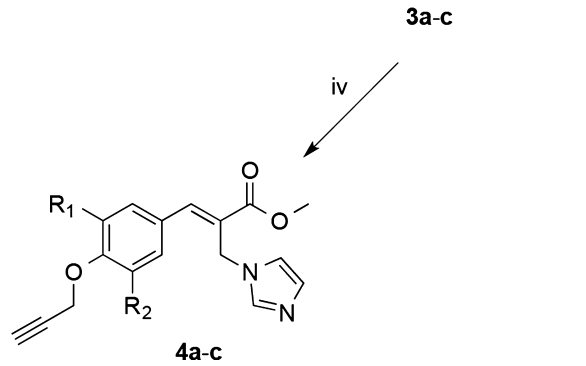

${ }^{a}$ Reagents: (i) propargyl bromide, $\mathrm{K}_{2} \mathrm{CO}_{3}$, and acetonitrile; (ii) methyl acrylate, 1,4-diazabicyclo[2.2.2] octane (DABCO), $\mathrm{CH}_{3} \mathrm{OH}$, and THF; (iii) $\mathrm{CH}_{3} \mathrm{COCl}$, triethylamine (TEA), and $\mathrm{CH}_{2} \mathrm{Cl}_{2}$; and (iv) imidazole, THF, and $\mathrm{H}_{2} \mathrm{O}$.

3a was prepared by a previously published procedure with the exception that the final esterification of $7 \mathbf{a}$ was performed with acetyl chloride. ${ }^{23}$ The MBHA derivative 3a was then made to react with 1.2 equiv of imidazole in tetrahydrofuran (THF)water (5:1) under reflux to obtain the imidazole derivative 4a.

MBHA derivatives $3 \mathbf{b}, \mathbf{c}$ bearing additional methoxy substituents were prepared by the same procedure starting from the appropriate aromatic aldehydes $\mathbf{5 b}$,c, which were converted into the corresponding propargyloxy derivatives $6 \mathbf{b}^{28}$ and $\mathbf{6} \mathbf{c}^{29}$ These compounds were then reacted with methyl acrylate in the presence of DABCO to provide MBHA alcohols $7 \mathbf{b}, \mathbf{c}$, which were in turn transformed into MBHA acetates $3 \mathbf{b}, \mathbf{c}$. Finally, compounds $3 \mathbf{b}, \mathbf{c}$ were made to react with 1.2 equiv of imidazole in THF-water (5:1) under reflux to obtain the imidazole derivatives $\mathbf{4 b , c}$ in $82-78 \%$ yields.

The UV-visible (UV-vis) absorption and emission spectra of imidazole derivatives $\mathbf{4 a}-\mathbf{c}$ are shown in Figure 2 for the compounds in diluted solution (i.e., $10^{-5} \mathrm{M}$ in methanol) and in the solid state (i.e., powders). Their main properties are compared in Table 1 in which the photoluminescence quantum 


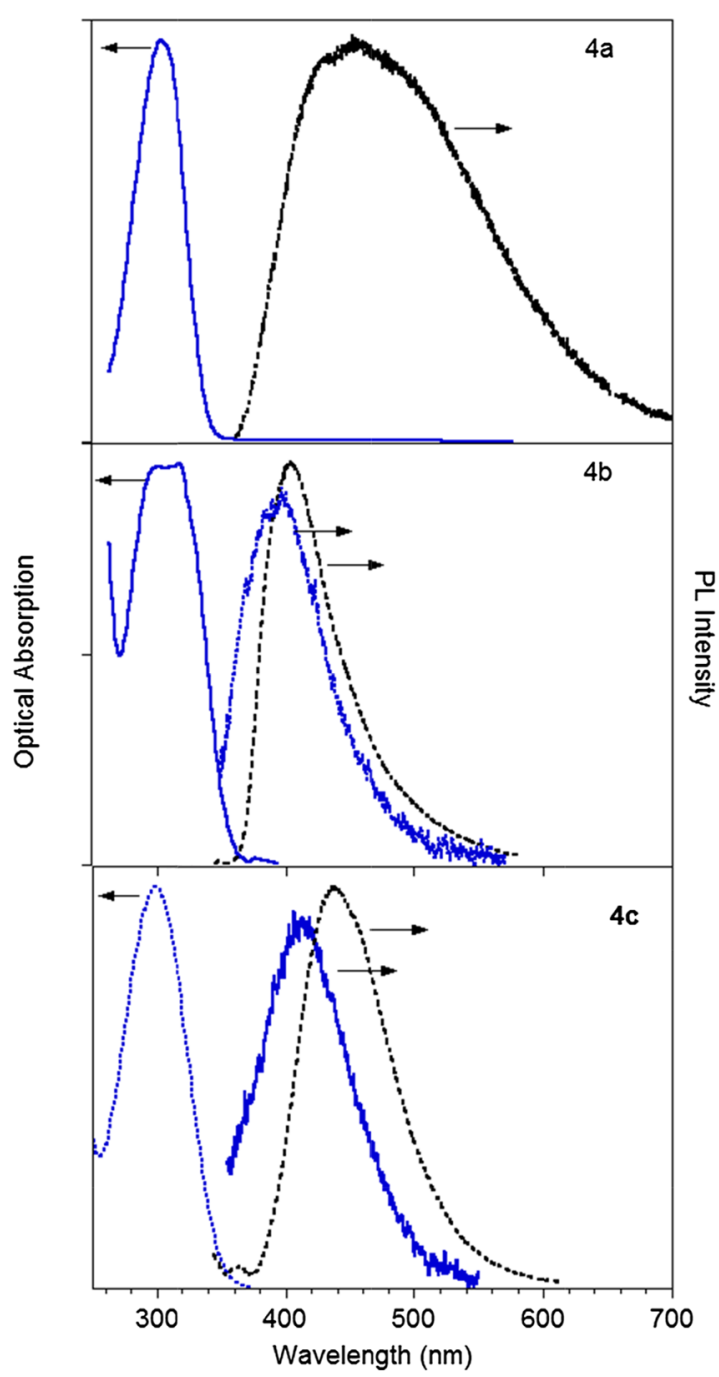

Figure 2. Optical properties of imidazole derivatives $4 a-c$. Absorption and emission spectra of the diluted methanol solutions (blue solid and dotted lines, respectively) and emission spectra of the powders (dashed black line).

Table 1. Optical Properties of Compounds $4 a-c$

\begin{tabular}{|c|c|c|c|c|c|c|}
\hline \multirow[b]{2}{*}{ compd } & \multicolumn{3}{|c|}{ solution } & \multicolumn{3}{|c|}{ powders } \\
\hline & $\begin{array}{c}\lambda_{\mathrm{ab}}{ }^{a} \\
(\mathrm{~nm})\end{array}$ & $\lambda_{\mathrm{em}}{ }^{b}(\mathrm{~nm})$ & $\begin{array}{c}\mathrm{PL} \mathrm{QY}^{c} \\
(\%)\end{array}$ & $\begin{array}{c}\lambda_{\mathrm{em}} \\
(\mathrm{nm})\end{array}$ & $\begin{array}{c}\mathrm{PL} \mathrm{QY}^{c} \\
(\%)\end{array}$ & $\tau^{d}(\mathrm{~ns})$ \\
\hline $4 a$ & 298 & $\begin{array}{l}420 \\
(393)^{e}\end{array}$ & 0.07 & 474 & $<0.1$ & 0.51 \\
\hline $4 b$ & 300 & $\begin{array}{l}395 \\
(390)^{e}\end{array}$ & 0.10 & 411 & 1 & 0.63 \\
\hline $4 c$ & 300 & ${ }^{400}(400)^{e}$ & 0.11 & 436 & 14 & 14.86 \\
\hline
\end{tabular}

yield $(\mathrm{PL} \mathrm{QY})^{30}$ is also reported. The three compounds show a very similar optical absorption, with a band peaked at about 300 $\mathrm{nm}$ in solution. The solutions are only weakly emissive, with PL QYs below 1\% and lifetimes below the experimental resolution (about $300 \mathrm{ps).} \mathrm{In} \mathrm{the} \mathrm{solid} \mathrm{state,} \mathrm{all} \mathrm{of} \mathrm{them} \mathrm{display} \mathrm{blue}$ emissions, rather weak for compound $\mathbf{4 a}$, increasing for compound $\mathbf{4 b}$, and becoming quite bright for compound $\mathbf{4 c}$. The weakly emissive compound 4 a shows a broad PL spectrum peaked at $474 \mathrm{~nm}$ with about $0.5 \mathrm{~ns}$ lifetime. A deeper photophysical analysis reveals that this broad emission is associated with the presence of a longer lived component (average lifetime of about $260 \mu \mathrm{s}$ ) with a red-shifted (500-600 $\mathrm{nm}$ ) spectrum (see Figure S1 in the Supporting Information). The methoxy $\mathbf{4 b}$ and dimethoxy $\mathbf{4 c}$ derivatives show narrow emission spectra peaked at $411 \mathrm{~nm}$ ( $0.6 \mathrm{~ns}$ lifetime) and 436 $\mathrm{nm}$ (15 ns lifetime), respectively, with the $4 \mathrm{c}$ derivative characterized by a PL QY as high as $14 \%$ (see Table 1 and Figure 2).

In order to understand the nature of the weak emission of the compounds in solution and to assess the mechanism responsible for the increase of their emission intensity in the solid state, we have performed a deeper analysis of the emission properties of compound $\mathbf{4 c}$ because its powders display the strongest emission intensity. The PL intensities of the compound dissolved in solvents with increasing polarities (THF or methanol) do not reveal any clear dependence on the solvent polarity, whereas an increase in the PL QY is observed by using a viscous solvent (PEG 400, QY $=1.3 \%$, see Figure S2 in the Supporting Information). This observation suggests that the origin of the weak emission in solution is ascribed to the intramolecular motions that are slowed down by increasing the solvent viscosity. ${ }^{26,31}$ We have then performed a PL analysis of 4c dissolved in methanol (good solvent) by adding a nonsolvent (water) while keeping constant its concentration (about $3.5 \times 10^{-5} \mathrm{M}$ ) in order to monitor the emission of the compound upon microaggregation in solution. The results, reported in Figure 3, show that the PL spectra progressively

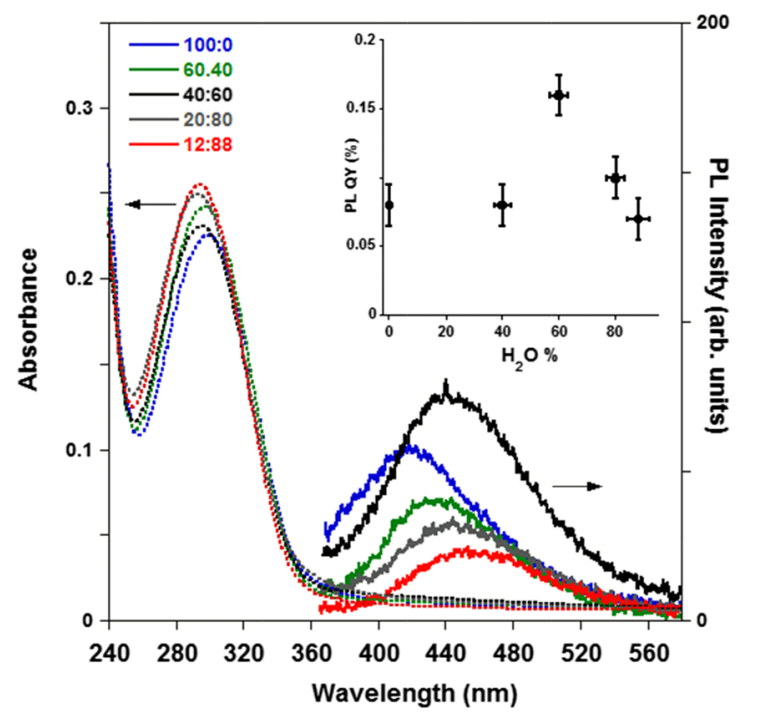

Figure 3. Optical absorption and PL of the imidazole derivative $4 \mathrm{c}$ in diluted methanol-water solutions for different methanol-water volume ratios. In the inset, the PL QY measured by exciting at 313 $\mathrm{nm}$ is plotted as a function of the water fraction.

red-shift from 415 to $450 \mathrm{~nm}$ by the addition of water while the PL intensity (see the inset of Figure 3 ) displays a clear increase at a water fraction of $60 \%$ and then decreases for higher water fractions. These results demonstrate that (i) the emission intensity of the compound is influenced by the environment rigidity rather than by its polarity and that (ii) a particular type of aggregation (occurring at about $60 \%$ of water fraction in methanol) is necessary to enhance the emission. Other organic compounds possessing a similar molecular structure have shown fluorescence strongly dependent on the nature of the aggregated particles and hence on the preparation meth- 
ods. $^{26,32-34}$ This behavior is typical of systems possessing crystallization-induced emission (CIE) properties. ${ }^{35}$ In these systems, the free intramolecular motions (vibrations and rotations) responsible for the solution emission quenching are active also in the aggregated state unless a strongly rigid solid-state packing is obtained. ${ }^{26,32,35}$ Only a very rigid environment, such as that of a tight crystal packing or a very rigid matrix, ${ }^{32,33}$ is capable of inhibiting the molecular motions responsible for the nonradiative deactivation of the excitations. For this reason, such compounds often display polymorphismdependent emissive properties and have recently shown interesting mechanofluorescence and thermofluorescence properties. $^{36,37}$

In order to verify if this mechanism is at the origin of the PL properties of the compounds $4 \mathbf{a}-\mathbf{c}$, we have studied their behavior in a good solvent when the diluted solution is frozen so that the molecular motions are blocked in the solutions. In Figure 4, we report the PL spectra of $4 \mathrm{c}$ in THF solution as

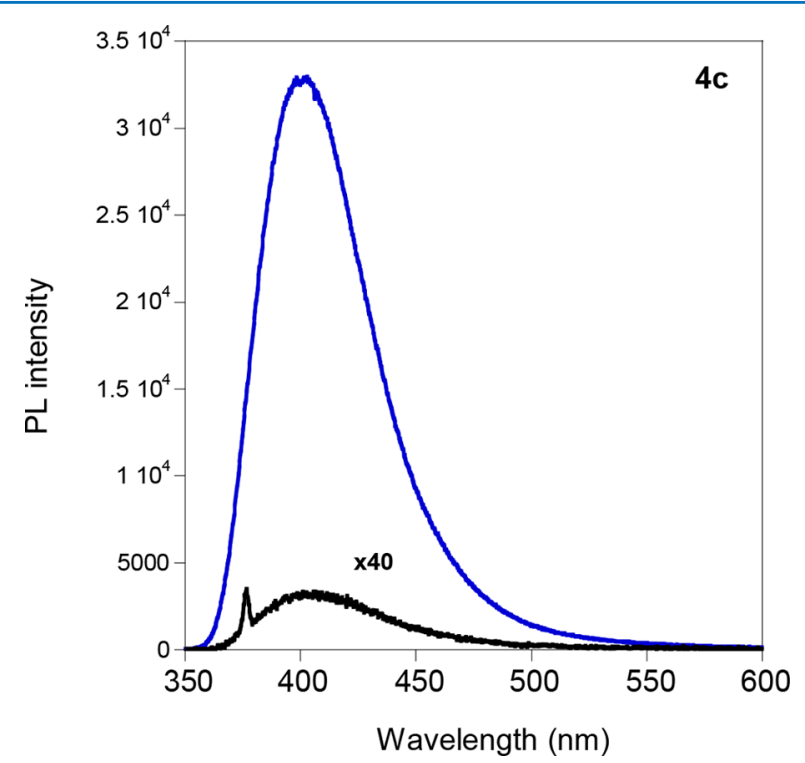

Figure 4. PL of the imidazole derivative $4 \mathrm{c}$ in diluted THF solution (concentration of $5 \times 10^{-4} \mathrm{M}$ ) at room temperature (black line) and at $77 \mathrm{~K}$ (blue line) (excitation at $340 \mathrm{~nm}$ ).

measured at room temperature and at $77 \mathrm{~K}$ (see Figures S3 and S4 in the Supporting Information for the PL spectra of $\mathbf{4 a}$ and b, respectively), and the PL emission maxima positions are reported in Table 1. For all compounds, a strong increase of the PL intensity (more than 2 orders of magnitude) is observed, in agreement with the presence of a quenching induced by the intramolecular motions in the solution at room temperature.

Interestingly, by comparing the PL spectra of the glassy solutions with those of the powders, we note that for compound 4a, a large spectral broadening and red shift are observed in the powder emission. In particular, the presence of a long lived component in the PL emission of 4 a powders might be associated to excimeric states formed by strong intermolecular interactions. From the comparison of the photophysical properties of the three compounds, we can therefore suggest that compound $4 \mathrm{c}$ displays the highest tendency to aggregate in a rigid packing where weak intermolecular interactions favors the emission, whereas a tight molecular packing in compound 4a introduces weakly emissive excimeric states accounting for the observed reduced emission efficiency. ${ }^{26}$ A combined structural and spectroscopic analysis of the three compounds in the solid state will further shed light on their complex photophysical behaviors.

\section{CONCLUSIONS}

With the aim of obtaining new fluorophores potentially useful in imidazole labeling and subsequent conjugation, a small series of Morita-Baylis-Hillman acetates $(3 \mathbf{a}-\mathbf{c})$ was designed, synthesized, and made to react with imidazole to obtain the corresponding imidazole derivatives $\mathbf{4 a - c}$, which were characterized from the point of view of their photophysical properties.

The analysis of the photophysical features showed that the three compounds display a very weak emission in solution. The starting imidazole derivative 4a failed in showing a significant emission in the solid state, which was instead observed in its methoxy and dimethoxy derivatives $\mathbf{4 b}$ and $\mathbf{4 c}$. These latter compounds featured the AIE, and in particular, the bright blue emission of compound $4 \mathrm{c}$ suggests the presence of CIE phenomenon, with PL QYs in the powders increased by 2 orders of magnitude with respect to the corresponding values measured in solution. The photophysical study confirmed the hypothesis that the molecular rigidity of the solid state enhances the emission properties of these compounds by triggering the RIM as it occurs for GFP fluorophores inside the protein. ${ }^{29}$ Moreover, the results emphasized $3 \mathrm{c}$ as an imidazolereactive molecule capable of forming a new AIE fluorophore bearing a "clickable" propargyl group potentially useful in the labeling of imidazole derivatives and subsequent conjugation.

\section{EXPERIMENTAL SECTION}

Chemistry. All chemicals used were of reagent grade. The yields refer to the purified products and are not optimized. The melting points were determined in open capillaries on a Gallenkamp apparatus and were uncorrected. Merck silica gel 60 (230-400 mesh) was used for column chromatography. Merck thin-layer chromatography (TLC) plates (silica gel 60 $\mathrm{F}_{254}$ ) were used for TLC. NMR spectra were recorded by means of either a DRX 400 AVANCE or a Bruker DRX 500 AVANCE spectrometer in the indicated solvents (tetramethylsilane as the internal standard); the values of the chemical shifts $(\delta)$ were expressed in ppm, and the coupling constants $(J)$ were expressed in in Hz. Mass spectra were recorded on an Agilent $1100 \mathrm{LC} / \mathrm{MSD}$.

General Procedure for the Preparation of Compounds $6 a-c$. A mixture of the suitable aldehyde derivative ( $\mathbf{5 a}-\mathbf{c}, 1$ equiv), potassium carbonate ( 3 equiv), and propargyl bromide ( $80 \mathrm{wt} \%, 3$ equiv) in acetonitrile was heated under reflux for $3 \mathrm{~h}$ and then concentrated under reduced pressure. The resulting residue was partitioned between ethyl acetate and water. The organic layer was dried over sodium sulfate and concentrated under reduced pressure. Purification of the residue by flash chromatography with the suitable eluent afforded the expected propargyloxy derivative $(6 \mathbf{6}-\mathbf{c})$.

4-(Prop-2-ynyloxy)benzaldehyde $(6 a) .^{23}$ The title compound was prepared from $5 \mathrm{a}(1.0 \mathrm{~g}, 8.2 \mathrm{mmol}), \mathrm{K}_{2} \mathrm{CO}_{3}(3.4 \mathrm{~g}$, $24.6 \mathrm{mmol})$, and propargyl bromide $(2.7 \mathrm{~mL}, 24.6 \mathrm{mmol})$ by following the above general procedure and purified by flash chromatography with petroleum ether-ethyl acetate (85:15) as the eluent to obtain compound $6 \mathrm{a}(1.2 \mathrm{~g}$, yield $91 \%)$. ${ }^{1} \mathrm{H}$ NMR $\left(400 \mathrm{MHz}, \mathrm{CDCl}_{3}\right): 2.56(\mathrm{t}, J=2.4 \mathrm{~Hz}, 1 \mathrm{H}), 4.78(\mathrm{~d}, J=2.4$ $\mathrm{Hz}, 2 \mathrm{H}), 7.08(\mathrm{~d}, J=8.8 \mathrm{~Hz}, 2 \mathrm{H}), 7.85(\mathrm{~d}, J=8.8 \mathrm{~Hz}, 2 \mathrm{H})$, 
$9.90(\mathrm{~s}, 1 \mathrm{H})$. MS (ESI) $m / z:[\mathrm{M}+\mathrm{H}]^{+}$calcd for $\mathrm{C}_{10} \mathrm{H}_{9} \mathrm{O}_{2}$, 161.1; found, 161.1.

3-Methoxy-4-(prop-2-ynyloxy)benzaldehyde $(6 \boldsymbol{b}) .^{28}$ The title compound was prepared from $5 \mathbf{b}(1.0 \mathrm{~g}, 6.6 \mathrm{mmol})$, $\mathrm{K}_{2} \mathrm{CO}_{3}(2.7 \mathrm{~g}, 19.8 \mathrm{mmol})$, and propargyl bromide $(2.2 \mathrm{~mL}$, $19.8 \mathrm{mmol}$ ) by following the above general procedure and purified by flash chromatography with petroleum ether-ethyl acetate $(85: 15)$ as the eluent to obtain compound $6 \mathrm{~b}(1.2 \mathrm{~g}$, yield $96 \%$ ) as a white solid melting at $87-88{ }^{\circ} \mathrm{C} .{ }^{1} \mathrm{H}$ NMR $\left(400 \mathrm{MHz}, \mathrm{CDCl}_{3}\right): 2.55(\mathrm{t}, J=2.4 \mathrm{~Hz}, 1 \mathrm{H}), 3.93(\mathrm{~s}, 3 \mathrm{H}), 4.85$ $(\mathrm{d}, J=2.4 \mathrm{~Hz}, 2 \mathrm{H}), 7.14(\mathrm{~d}, J=8.1 \mathrm{~Hz}, 1 \mathrm{H}), 7.42(\mathrm{~d}, J=1.6$ $\mathrm{Hz}, 1 \mathrm{H}), 7.45$ (dd, $J=8.1,1.6 \mathrm{~Hz}, 1 \mathrm{H}), 9.86(\mathrm{~s}, 1 \mathrm{H})$. MS (ESI) $m / z:[\mathrm{M}+\mathrm{H}]^{+}$calcd for $\mathrm{C}_{11} \mathrm{H}_{11} \mathrm{O}_{3}$, 191.1; found, 191.1.

3,5-Dimethoxy-4-(prop-2-ynyloxy)benzaldehyde (6c). ${ }^{29}$ The title compound was prepared from $5 \mathrm{c}(1.0 \mathrm{~g}, 5.5 \mathrm{mmol})$, $\mathrm{K}_{2} \mathrm{CO}_{3}(2.3 \mathrm{~g}, 16.6 \mathrm{mmol})$, and propargyl bromide $(1.8 \mathrm{~mL}$, $16.5 \mathrm{mmol}$ ) by following the above general procedure and purified by flash chromatography with petroleum ether-ethyl acetate-dichloromethane $(7: 2: 1)$ as the eluent to obtain compound $6 \mathrm{c}(1.1 \mathrm{~g}$, yield $91 \%)$ as a white solid melting at 112-113 ${ }^{\circ} \mathrm{C}$ (lit. $\left.{ }^{29}{ }^{108-109}{ }^{\circ} \mathrm{C}\right) .{ }^{1} \mathrm{H}$ NMR $(400 \mathrm{MHz}$, $\left.\mathrm{CDCl}_{3}\right): 2.43(\mathrm{t}, J=2.4 \mathrm{~Hz}, 1 \mathrm{H}), 3.93(\mathrm{~s}, 6 \mathrm{H}), 4.83(\mathrm{~d}, J=2.4$ $\mathrm{Hz}, 2 \mathrm{H}), 7.13(\mathrm{~s}, 2 \mathrm{H}), 9.87(\mathrm{~s}, 1 \mathrm{H})$. MS (ESI) $\mathrm{m} / z:[\mathrm{M}+\mathrm{H}]^{+}$ calcd for $\mathrm{C}_{12} \mathrm{H}_{13} \mathrm{O}_{4}, 221.1$; found, 221.1.

General Procedure for the Preparation of Compounds $7 \mathrm{a}-\mathrm{c}$. A mixture of the appropriate aldehyde $(6 \mathrm{a}-$ c) in the suitable solvent containing the suitable amounts of methyl acrylate and of DABCO was stirred at room temperature for $48 \mathrm{~h}$ in darkness and then concentrated under reduced pressure. The resulting residue was dissolved in ethyl acetate and washed in sequence with water, $1 \mathrm{~N} \mathrm{HCl}$, and brine. The organic layer was dried over sodium sulfate and concentrated under reduced pressure. Purification of the residue by flash chromatography with the suitable eluent afforded the expected acrylate derivative $(7 \mathbf{a}-\mathbf{c})$.

Methyl 2-[Hydroxy[4-(prop-2-ynyloxy)phenyl]methyl]acrylate $(7 a){ }^{23}$ The title compound was prepared from $\mathbf{6 a}$ $(0.50 \mathrm{~g}, 3.1 \mathrm{mmol})$, methanol $(10 \mathrm{~mL})$, THF $(5.0 \mathrm{~mL})$, methyl acrylate $(10 \mathrm{~mL})$, and DABCO $(0.35 \mathrm{~g}, 3.1 \mathrm{mmol})$ by following the above general procedure and purified by flash chromatography with petroleum ether-ethyl acetate (8:2) as the eluent to obtain compound $7 \mathbf{a}(0.24 \mathrm{~g}$, yield $31 \%)$ as a colorless oil. ${ }^{1} \mathrm{H}$ $\operatorname{NMR}\left(400 \mathrm{MHz}, \mathrm{CDCl}_{3}\right): 2.50(\mathrm{t}, J=2.4 \mathrm{~Hz}, 1 \mathrm{H}), 2.85(\mathrm{~d}, J=$ $5.4 \mathrm{~Hz}, 1 \mathrm{H}), 3.72(\mathrm{~s}, 3 \mathrm{H}), 4.68(\mathrm{~d}, J=2.4 \mathrm{~Hz}, 2 \mathrm{H}), 5.53(\mathrm{~d}, J=$ $5.4 \mathrm{~Hz}, 1 \mathrm{H}), 5.83(\mathrm{~s}, 1 \mathrm{H}), 6.32(\mathrm{~s}, 1 \mathrm{H}), 6.91-6.99(\mathrm{~m}, 2 \mathrm{H})$, 7.27-7.34 (m, 2H). MS (ESI) $m / z:[\mathrm{M}+\mathrm{Na}]^{+}$calcd for $\mathrm{C}_{14} \mathrm{H}_{14} \mathrm{O}_{4} \mathrm{Na}$, 269.1; found, 269.0.

Methyl 2-[Hydroxyl[3-methoxy-4-(prop-2-ynyloxy)phenyl]methyl]acrylate ( $7 b)$. The title compound was prepared from $6 \mathbf{b}(1.2 \mathrm{~g}, 6.3 \mathrm{mmol})$, methanol $(15 \mathrm{~mL})$, THF $(7.0 \mathrm{~mL})$, methyl acrylate $(15 \mathrm{~mL})$, and DABCO $(0.71 \mathrm{~g}$, $6.3 \mathrm{mmol}$ ) by following the above general procedure and purified by flash chromatography with petroleum ether-ethyl acetate $(8: 2)$ as the eluent to obtain compound $7 \mathbf{b}(0.26 \mathrm{~g}$, yield $15 \%)$ as a colorless oil. ${ }^{1} \mathrm{H}$ NMR $\left(400 \mathrm{MHz}, \mathrm{CDCl}_{3}\right)$ : $2.49(\mathrm{t}, J=2.4 \mathrm{~Hz}, 1 \mathrm{H}), 2.94(\mathrm{~d}, J=5.6 \mathrm{~Hz}, 1 \mathrm{H}), 3.73(\mathrm{~s}, 3 \mathrm{H})$, $3.87(\mathrm{~s}, 3 \mathrm{H}), 4.74(\mathrm{~d}, J=2.4 \mathrm{~Hz}, 2 \mathrm{H}), 5.52(\mathrm{~d}, J=5.4 \mathrm{~Hz}, 1 \mathrm{H})$, $5.82(\mathrm{~s}, 1 \mathrm{H}), 6.33(\mathrm{~s}, 1 \mathrm{H}), 6.88(\mathrm{dd}, J=8.2,2.0 \mathrm{~Hz}, 1 \mathrm{H}), 6.96$ $(\mathrm{d}, J=2.0 \mathrm{~Hz}, 1 \mathrm{H}), 6.99(\mathrm{~d}, J=8.2 \mathrm{~Hz}, 1 \mathrm{H}) .{ }^{13} \mathrm{C}$ NMR $(125$ $\mathrm{MHz}, \mathrm{CDCl}_{3}$ ): 52.0, 55.9, 56.8, 73.0, 75.8, 78.6, 110.2, 114.0, 118.7, 126.1, 135.2, 141.9, 146.4, 149.6, 166.8. MS (ESI) $\mathrm{m} / z$ : $[\mathrm{M}+\mathrm{Na}]^{+}$calcd for $\mathrm{C}_{15} \mathrm{H}_{16} \mathrm{O}_{5} \mathrm{Na}$, 299.1; found, 299.1.
Methyl 2-[[3,5-Dimethoxy-4-(prop-2-ynyloxy)phenyl](hydroxy)methyl]acrylate (7c). The title compound was prepared from $6 \mathrm{c}(0.94 \mathrm{~g}, 4.3 \mathrm{mmol})$, methanol $(6.0 \mathrm{~mL})$, THF $(4.0 \mathrm{~mL})$, methyl acrylate $(6.0 \mathrm{~mL})$, and DABCO $(0.48 \mathrm{~g}$, $4.3 \mathrm{mmol}$ ) by following the above general procedure and purified by flash chromatography with petroleum ether-ethyl acetate $(8: 2)$ as the eluent to obtain compound $7 \mathrm{c}(0.55 \mathrm{~g}$, yield $42 \%$ ) as a pale yellow oil, which crystallized on standing [melting point (mp) 52-53 ${ }^{\circ} \mathrm{C}$ ]. ${ }^{1} \mathrm{H}$ NMR $(400 \mathrm{MHz}$, $\left.\mathrm{CDCl}_{3}\right): 2.42(\mathrm{t}, J=2.4 \mathrm{~Hz}, 1 \mathrm{H}), 3.03(\mathrm{~d}, J=5.7 \mathrm{~Hz}, 1 \mathrm{H})$, $3.75(\mathrm{~s}, 3 \mathrm{H}), 3.84(\mathrm{~s}, 6 \mathrm{H}), 4.69(\mathrm{~d}, J=2.4 \mathrm{~Hz}, 2 \mathrm{H}), 5.50(\mathrm{~d}, J=$ $5.5 \mathrm{~Hz}, 1 \mathrm{H}), 5.79(\mathrm{~s}, 1 \mathrm{H}), 6.33(\mathrm{~s}, 1 \mathrm{H}), 6.60(\mathrm{~s}, 2 \mathrm{H}) .{ }^{13} \mathrm{C} \mathrm{NMR}$ $\left(125 \mathrm{MHz}, \mathrm{CDCl}_{3}\right): 52.1,56.2,59.9,73.3,74.8,79.4,103.5$, 126.4, 135.0, 137.5, 141.7, 153.3, 166.9. MS (ESI) $\mathrm{m} / z:[\mathrm{M}+$ $\mathrm{Na}]^{+}$calcd for $\mathrm{C}_{16} \mathrm{H}_{18} \mathrm{O}_{6} \mathrm{Na}$, 329.1; found, 329.0.

General Procedure for the Preparation of Compounds $3 a-c$. To a solution of the suitable alcohol $(7 \mathbf{a}-\mathbf{c})$ in dry dichloromethane containing TEA (2.5 equiv), acetyl chloride (2.0 equiv) was added dropwise. After stirring at room temperature for $1 \mathrm{~h}$, the reaction mixture was washed with water. The organic layer was dried over sodium sulfate and concentrated under reduced pressure. The residue was purified by flash chromatography with petroleum ether-ethyl acetate $(8: 2)$ as the eluent to afford the corresponding acetate $(3 \mathbf{a}-\mathbf{c})$.

Methyl 2-[Acetoxy[4-(prop-2-ynyloxy)phenyl]methyl]acrylate (3a). The title compound was prepared from $7 \mathbf{a}$ $(0.10 \mathrm{~g}, 0.406 \mathrm{mmol})$, TEA $(0.14 \mathrm{~mL}, 1.00 \mathrm{mmol})$, dry dichloromethane $(10 \mathrm{~mL})$, and acetyl chloride $(0.058 \mathrm{~mL}$, $0.812 \mathrm{mmol}$ ) by following the above general procedure to obtain compound $3 \mathrm{a}(0.105 \mathrm{~g}$, yield $90 \%)$ as a colorless oil. ${ }^{1} \mathrm{H}$ NMR $\left(500 \mathrm{MHz}, \mathrm{CDCl}_{3}\right): 2.06(\mathrm{~s}, 3 \mathrm{H}), 2.51(\mathrm{t}, J=2.4 \mathrm{~Hz}$, $1 \mathrm{H}), 3.69(\mathrm{~s}, 3 \mathrm{H}), 4.66(\mathrm{~d}, J=2.4 \mathrm{~Hz}, 2 \mathrm{H}), 5.86(\mathrm{~s}, 1 \mathrm{H}), 6.37$ $(\mathrm{s}, 1 \mathrm{H}), 6.63(\mathrm{~s}, 1 \mathrm{H}), 6.93(\mathrm{~d}, J=8.8 \mathrm{~Hz}, 2 \mathrm{H}), 7.31(\mathrm{~d}, J=8.4$ $\mathrm{Hz}, 2 \mathrm{H}) .{ }^{13} \mathrm{C}$ NMR $\left(125 \mathrm{MHz}, \mathrm{CDCl}_{3}\right): 21.2,52.0,55.8,72.7$, 75.7, 78.4, 114.8, 125.3, 129.2, 130.8, 139.6, 157.6, 165.4, 169.5. MS (ESI) $m / z:[\mathrm{M}+\mathrm{Na}]^{+}$calcd for $\mathrm{C}_{16} \mathrm{H}_{16} \mathrm{O}_{5} \mathrm{Na}$, 311.1; found, 311.0.

Methyl 2-[Acetoxy[3-methoxy-4-(prop-2-ynyloxy)phenyl]methyl]acrylate (3b). The title compound was prepared from $7 \mathbf{b}(0.10 \mathrm{~g}, 0.36 \mathrm{mmol})$, TEA $(0.13 \mathrm{~mL}, 0.905 \mathrm{mmol})$, dry dichloromethane $(10 \mathrm{~mL})$, and acetyl chloride $(0.051 \mathrm{~mL}$, $0.724 \mathrm{mmol}$ ) by following the above general procedure to obtain compound $\mathbf{3 b}(0.090 \mathrm{~g}$, yield $78 \%)$ as a colorless oil. ${ }^{1} \mathrm{H}$ NMR $\left(500 \mathrm{MHz}, \mathrm{CDCl}_{3}\right): 2.10(\mathrm{~s}, 3 \mathrm{H}), 2.49(\mathrm{t}, J=2.2 \mathrm{~Hz}$, $1 \mathrm{H}), 3.70(\mathrm{~s}, 3 \mathrm{H}), 3.86(\mathrm{~s}, 3 \mathrm{H}), 4.74(\mathrm{~d}, J=2.3 \mathrm{~Hz}, 2 \mathrm{H}), 5.86$ $(\mathrm{s}, 1 \mathrm{H}), 6.38(\mathrm{~s}, 1 \mathrm{H}), 6.63(\mathrm{~s}, 1 \mathrm{H}), 6.88-6.94(\mathrm{~m}, 2 \mathrm{H}), 6.98(\mathrm{~d}$, $J=8.2 \mathrm{~Hz}, 1 \mathrm{H}) .{ }^{13} \mathrm{C}$ NMR $\left(125 \mathrm{MHz}, \mathrm{CDCl}_{3}\right): 21.2,52.1$, 55.9, 56.7, 72.9, 75.9, 78.4, 111.4, 113.7, 120.1, 125.4, 131.5, 139.6, 146.9, 149.4, 165.5, 169.5. MS (ESI) $\mathrm{m} / z:[\mathrm{M}+\mathrm{Na}]^{+}$ calcd for $\mathrm{C}_{17} \mathrm{H}_{18} \mathrm{O}_{6} \mathrm{Na}$, 341.1; found, 341.0.

Methyl 2-[Acetoxy[3,5-dimethoxy-4-(prop-2-ynyloxy)phenyl]methyl]acrylate (3c). The title compound was prepared from $7 \mathrm{c}(0.20 \mathrm{~g}, 0.65 \mathrm{mmol})$, TEA $(0.27 \mathrm{~mL}, 1.95$ $\mathrm{mmol})$, dry dichloromethane $(10 \mathrm{~mL})$, and acetyl chloride $(0.092 \mathrm{~mL}, 1.3 \mathrm{mmol})$ by following the above general procedure to obtain compound $3 \mathrm{c}(0.18 \mathrm{~g}$, yield $79 \%)$ as a white solid melting at $76-77{ }^{\circ} \mathrm{C} .{ }^{1} \mathrm{H}$ NMR $(500 \mathrm{MHz}$, $\left.\mathrm{CDCl}_{3}\right): 2.12(\mathrm{~s}, 3 \mathrm{H}), 2.43(\mathrm{t}, J=2.4 \mathrm{~Hz}, 1 \mathrm{H}), 3.72(\mathrm{~s}, 3 \mathrm{H})$, $3.83(\mathrm{~s}, 6 \mathrm{H}), 4.68(\mathrm{~d}, J=2.4 \mathrm{~Hz}, 2 \mathrm{H}), 5.84(\mathrm{~s}, 1 \mathrm{H}), 6.39(\mathrm{~s}$, $1 \mathrm{H}), 6.57(\mathrm{~s}, 2 \mathrm{H}), 6.62(\mathrm{~s}, 1 \mathrm{H}) .{ }^{13} \mathrm{C} \mathrm{NMR}\left(125 \mathrm{MHz}, \mathrm{CDCl}_{3}\right)$ : $21.2,52.1,56.2,60.0,73.1,74.8,79.4,104.8,125.8,133.9$, 135.6, 139.5, 153.4, 165.4, 169.4. MS (ESI) $m / z:[\mathrm{M}+\mathrm{Na}]^{+}$ calcd for $\mathrm{C}_{18} \mathrm{H}_{20} \mathrm{O}_{7} \mathrm{Na}$, 371.1; found, 371.1. 
General Procedure for the Preparation of Imidazole

Derivatives $4 a-c$. A mixture of the appropriate acetate (3ac) in THF-water (5:1) containing imidazole (1.2 equiv) was heated under reflux overnight. After cooling to room temperature, the reaction mixture was diluted with brine and extracted with dichloromethane. The organic layer was dried over sodium sulfate and concentrated under reduced pressure. Purification of the residue by flash chromatography with ethyl acetate as the eluent gave the corresponding imidazole derivative $(4 a-c)$.

(E)-Methyl 2-[(1H-Imidazol-1-yl)methyl]-3-[4-(prop-2ynyloxy)phenyl]acrylate (4a). The title compound was prepared from 3a $(50 \mathrm{mg}, 0.173 \mathrm{mmol})$, imidazole $(14 \mathrm{mg}$, $0.208 \mathrm{mmol})$, THF $(5.0 \mathrm{~mL})$, and water $(1.0 \mathrm{~mL})$ to obtain compound $4 \mathrm{a}(42 \mathrm{mg}$, yield $82 \%)$ as an off-white solid melting at $103-104{ }^{\circ} \mathrm{C} .{ }^{1} \mathrm{H}$ NMR $\left(400 \mathrm{MHz} \mathrm{CDCl}_{3}\right): 2.54$ (t, $J=2.4$ $\mathrm{Hz}, 1 \mathrm{H}), 3.80(\mathrm{~s}, 3 \mathrm{H}), 4.72(\mathrm{~d}, J=2.4 \mathrm{~Hz}, 2 \mathrm{H}), 4.99(\mathrm{~s}, 2 \mathrm{H})$, $6.89(\mathrm{~s}, 1 \mathrm{H}), 6.96-7.06(\mathrm{~m}, 3 \mathrm{H}), 7.26-7.36(\mathrm{~m}, 2 \mathrm{H}), 7.49(\mathrm{~s}$, $1 \mathrm{H}), 7.98(\mathrm{~s}, 1 \mathrm{H}) .{ }^{13} \mathrm{C} \mathrm{NMR}\left(125 \mathrm{MHz}, \mathrm{CDCl}_{3}\right): 43.2,52.5$, 55.8, 76.2, 77.9, 115.4, 118.7, 124.8, 127.1, 129.3, 130.9, 136.9, 144.6, 158.8, 167.2. MS (ESI) $m / z:[\mathrm{M}+\mathrm{H}]^{+}$calcd for $\mathrm{C}_{17} \mathrm{H}_{17} \mathrm{~N}_{2} \mathrm{O}_{3}$, 297.1; found, 297.0.

(E)-Methyl 2-[(1H-Imidazol-1-yl)methyl]-3-[3-methoxy-4(prop-2-ynyloxy)phenyl]acrylate (4b). The title compound was prepared from $3 \mathbf{b}(50 \mathrm{mg}, 0.157 \mathrm{mmol})$, imidazole $(13 \mathrm{mg}$, $0.188 \mathrm{mmol})$, THF $(5.0 \mathrm{~mL})$, and water $(1.0 \mathrm{~mL})$ to obtain compound $4 \mathrm{~b}$ ( $42 \mathrm{mg}$, yield $82 \%$ ) as a pale yellow oil which crystallized on standing (mp 101-104 $\left.{ }^{\circ} \mathrm{C}\right) .{ }^{1} \mathrm{H}$ NMR (500 $\left.\mathrm{MHz}, \mathrm{CDCl}_{3}\right): 2.53(\mathrm{t}, J=2.4 \mathrm{~Hz}, 1 \mathrm{H}), 3.79(\mathrm{~s}, 3 \mathrm{H}), 3.81(\mathrm{~s}$, $3 \mathrm{H}), 4.79(\mathrm{~d}, J=2.4 \mathrm{~Hz}, 2 \mathrm{H}), 5.02(\mathrm{~s}, 2 \mathrm{H}), 6.80(\mathrm{~d}, J=1.9 \mathrm{~Hz}$, $1 \mathrm{H}), 6.89-6.96(\mathrm{~m}, 2 \mathrm{H}), 7.02-7.08(\mathrm{~m}, 2 \mathrm{H}), 7.56(\mathrm{br} \mathrm{s}, 1 \mathrm{H})$, 8.00 (s, $1 \mathrm{H}) .{ }^{13} \mathrm{C} \mathrm{NMR}\left(125 \mathrm{MHz}, \mathrm{CDCl}_{3}\right): 43.5,52.6,55.9$, 56.6, 76.4, 77.8, 112.5, 113.8, 118.8, 122.2, 124.7, 127.6, 129.1, 136.7, 145.2, 148.2, 149.7, 167.2. MS (ESI) $\mathrm{m} / z:[\mathrm{M}+\mathrm{H}]^{+}$ calcd for $\mathrm{C}_{18} \mathrm{H}_{19} \mathrm{~N}_{2} \mathrm{O}_{4}, 327.1$; found, 327.0.

(E)-Methyl 2-[(1H-Imidazol-1-yl)methyl]-3-[3,5-dimethoxy4-(prop-2-ynyloxy)phenyl]acrylate (4c). The title compound was prepared from $3 \mathrm{c}(50 \mathrm{mg}, 0.144 \mathrm{mmol})$, imidazole $(12 \mathrm{mg}$, $0.173 \mathrm{mmol})$, THF $(5.0 \mathrm{~mL})$, and water $(1.0 \mathrm{~mL})$ to obtain compound $4 \mathrm{c}(40 \mathrm{mg}$, yield $78 \%)$ as a colorless oil which crystallized on standing (mp 99-100 $\left.{ }^{\circ} \mathrm{C}\right) .{ }^{1} \mathrm{H}$ NMR $(500 \mathrm{MHz}$, $\left.\mathrm{CDCl}_{3}\right): 2.44(\mathrm{t}, J=2.4 \mathrm{~Hz}, 1 \mathrm{H}), 3.77(\mathrm{~s}, 6 \mathrm{H}), 3.82(\mathrm{~s}, 3 \mathrm{H})$, $4.75(\mathrm{~d}, J=2.4 \mathrm{~Hz}, 2 \mathrm{H}), 5.00(\mathrm{~s}, 2 \mathrm{H}), 6.48(\mathrm{~s}, 2 \mathrm{H}), 6.91(\mathrm{~s}$, $1 \mathrm{H}), 7.06(\mathrm{~s}, 1 \mathrm{H}), 7.52(\mathrm{~s}, 1 \mathrm{H}), 8.00(\mathrm{~s}, 1 \mathrm{H}) .{ }^{13} \mathrm{C}$ NMR $(125$ $\left.\mathrm{MHz}, \mathrm{CDCl}_{3}\right)$ : 43.4, 52.6, 56.2, 60.0, 75.2, 79.0, 106.1, 118.6, $125.9,129.4,129.9,136.8,145.4,153.8,167.0$. MS (ESI) $\mathrm{m} / z$ : $[\mathrm{M}+\mathrm{H}]^{+}$calcd for $\mathrm{C}_{19} \mathrm{H}_{21} \mathrm{~N}_{2} \mathrm{O}_{5}, 357.1$; found, 357.1.

Optical Properties and PL. UV-vis absorption spectra were obtained with a PerkinElmer LAMBDA 900 spectrometer. PL spectra were obtained with a SPEX 270M monochromator equipped with a $\mathrm{N}_{2}$-cooled charge-coupled device exciting with a monochromated $450 \mathrm{~W}$ Xe lamp. The spectra were corrected for the instrument response. PL QY values of the solutions were obtained by using quinine sulfate as the reference, with an experimental error of about $5 \%$ for values below $0.1 \%$. PL QY values of the solid powders were measured with a homemade integrating sphere, with an experimental error of $10 \%$ and a sensitivity of about $0.1 \%$, according to the procedure reported elsewhere. $^{30}$ Time-resolved studies of the emission were performed with a Nanolog spectrofluorometer with a DeltaTime TCSPC (time-correlated single-photon counting) equipped with a single-photon detection module PPD- 850 by exciting with a DeltaDiode source at $300 \mathrm{~nm}$ or a pulsed Xe lamp.

\section{ASSOCIATED CONTENT}

\section{Supporting Information}

The Supporting Information is available free of charge on the ACS Publications website at DOI: 10.1021/acsomega.7b00789.

Prompt PL and delayed emission of 4 a powders; absorption and PL spectra of $4 c$ in PEG; PL spectra of $\mathbf{4 a}$ and $\mathbf{4 b}$ in diluted THF solution at room temperature and at $77 \mathrm{~K}$; and ${ }^{1} \mathrm{H}$ and ${ }^{13} \mathrm{C}$ NMR of compounds $4 a-c$ and of their intermediates (PDF)

\section{AUTHOR INFORMATION}

\section{Corresponding Authors}

*E-mail: chiara.botta@ismac.cnr.it. Phone: +39 0223699734 (C.B.).

*E-mail: andrea.cappelli@unisi.it. Phone: +390577 234320 (A.C.).

ORCID $\odot$

Marco Paolino: 0000-0003-1387-7875

Chiara Botta: 0000-0001-8722-0417

Andrea Cappelli: 0000-0003-4140-3028

\section{Author Contributions}

The manuscript was written through the contributions of all authors.

\section{Notes}

The authors declare no competing financial interest.

\section{REFERENCES}

(1) Xi, N.; Huang, Q; Liu, L. Imidazoles. In Comprehensive Heterocyclic Chemistry III, Five-membered Rings with Two Heteroatoms, Each with Their Fused Carbocyclic Derivatives; Katritzky, A. R, Ramsden, C. A., Scriven, E. F. V., Taylor, R. J. K., Eds.; Elsevier: Oxford, 2008; Vol. 4, pp 143-364.

(2) Richaud, A.; Barba-Behrens, N.; Méndez, F. Chemical reactivity of the imidazole: A semblance of pyridine and pyrrole? Org. Lett. 2011, 13, 972-975.

(3) Narasimhan, B.; Sharma, D.; Kumar, P. Biological importance of imidazole nucleus in the new millennium. Med. Chem. Res. 2011, 20, $1119-1140$.

(4) Zhang, L.; Peng, X.-M.; Damu, G. L. V.; Geng, R.-X.; Zhou, C.-H. Comprehensive review in current developments of imidazole-based medicinal chemistry. Med. Res. Rev. 2014, 34, 340-437.

(5) Barnard, E. A.; Stein, W. D. The roles of imidazole in biological systems. In Advances in Enzymology and Related Areas of Molecular Biology; Nord, F. F., Ed.; Wiley, 2006; Vol. 20, pp 51-110.

(6) Sundberg, R. J.; Martin, R. B. Interactions of histidine and other imidazole derivatives with transition metal ions in chemical and biological systems. Chem. Rev. 1974, 74, 471-517.

(7) Matuszak, C. A.; Matuszak, A. J. Imidazole-versatile today, prominent tomorrow. J. Chem. Educ. 1976, 53, 280-284.

(8) Chen, X.; Wu, Y.-W. Selective chemical labeling of proteins. Org. Biomol. Chem. 2016, 14, 5417-5439.

(9) Dean, K. M.; Palmer, A. E. Advances in fluorescence labeling strategies for dynamic cellular imaging. Nat. Chem. Biol. 2014, 10, $512-523$.

(10) Chen, Y.; Tsao, K.; Keillor, J. W. Fluorogenic protein labelling: a review of photophysical quench mechanisms and principles of fluorogen design. Can. J. Chem. 2015, 93, 389-398.

(11) Uchinomiya, S.; Ojida, A.; Hamachi, I. Peptide tag/probe pairs based on the coordination chemistry for protein labeling. Inorg. Chem. 2014, 53, 1816-1823. 
(12) Kapanidis, A. N.; Ebright, Y. W.; Ebright, R. H. Site-specific incorporation of fluorescent probes into protein: hexahistidine-tagmediated fluorescent labeling with (Ni2+:nitrilotriacetic acid)nfluorochrome conjugates. J. Am. Chem. Soc. 2001, 123, 12123-12125.

(13) Lai, Y.-T.; Chang, Y.-Y.; Hu, L.; Yang, Y.; Chao, A.; Du, Z.-Y.; Tanner, J. A.; Chye, M.-L.; Qian, C.; Ng, K.-M.; Li, H.; Sun, H. Rapid labeling of intracellular His-tagged proteins in living cells. Proc. Natl. Acad. Sci. U.S.A. 2015, 112, 2948-2953.

(14) Wang, Z.; Ding, X.; Li, S.; Shi, J.; Li, Y. Engineered fluorescence tags for in vivo protein labelling. RSC Adv. 2014, 4, 7235-7245.

(15) Rong, L.; Zhang, C.; Lei, Q.; Qin, S.-Y.; Feng, J.; Zhang, X.-Z. A two-photon excitation based fluorogenic probe for sialome imaging in living systems. Adv. Sci. 2016, 3, 1500211

(16) Lavis, L. D.; Chao, T.-Y.; Raines, R. T. Fluorogenic label for biomolecular imaging. ACS Chem. Biol. 2006, 1, 252-260.

(17) Hong, Y. Aggregation-induced emission-fluorophores and applications. Methods Appl. Fluoresc. 2016, 4, 022003.

(18) Mei, J.; Leung, N. L. C.; Kwok, R. T. K.; Lam, J. W. Y.; Tang, B. Z. Aggregation-induced emission: together we shine, united we soar! Chem. Rev. 2015, 115, 11718-11940.

(19) Ding, D.; Li, K.; Liu, B.; Tang, B. Z. Bioprobes based on AIE fluorogens. Acc. Chem. Res. 2013, 46, 2441-2453.

(20) Wu, W.-C.; Chen, C.-Y.; Tian, Y.; Jang, S.-H.; Hong, Y.; Liu, Y.; Hu, R.; Tang, B. Z.; Lee, Y.-T.; Chen, C.-T.; Chen, W.-C.; Jen, A. K.-Y. Enhancement of aggregation-induced emission in dye-encapsulating polymeric micelles for bioimaging. Adv. Funct. Mater. 2010, 20, 14131423.

(21) Rodrigues, M. T., Jr.; Santos, M. S.; Santos, H.; Coelho, F. 1,1'Carbonyldiimidazole mediates the synthesis of N-substituted imidazole derivatives from Morita-Baylis-Hillman adducts. Tetrahedron Lett. 2014, 55, 180-183.

(22) Li, J.; Wang, X.; Zhang, Y. Remarkable rate acceleration of water-promoted nucleophilic substitution of Baylis-Hillman acetate: a facile and highly efficient synthesis of $\mathrm{N}$-substituted imidazole. Tetrahedron Lett. 2005, 46, 5233-5237.

(23) Liu, X. X.; Melman, A. Templated alkylation of hexahistidine with Baylis-Hillman esters. Chem. Commun. 2013, 49, 9042-9044.

(24) Kim, E.; Lee, Y.; Lee, S.; Park, S. B. Discovery, understanding, and bioapplication of organic fluorophore: a case study with an indolizine-based novel fluorophore, Seoul-Fluor. Acc. Chem. Res. 2015, $48,538-547$.

(25) Wang, C.; Huang, H.; Bunes, B. R.; Wu, N.; Xu, M.; Yang, X.; Yu, L.; Zang, L. Trace detection of RDX, HMX and PETN explosives using a fluorescence spot sensor. Sci. Rep. 2016, 6, 25015.

(26) Cariati, E.; Lanzeni, V.; Tordin, E.; Ugo, R.; Botta, C.; Schieroni, A. G.; Sironi, A.; Pasini, D. Efficient crystallization induced emissive materials based on a simple push-pull molecular structure. Phys. Chem. Chem. Phys. 2011, 13, 18005-18014.

(27) Plamont, M.-A.; Billon-Denis, E.; Maurin, S.; Gauron, C.; Pimenta, F. M.; Specht, C. G.; Shi, J.; Quérard, J.; Pan, B.; Rossignol, J.; Moncoq, K.; Morellet, N.; Volovitch, M.; Lescop, E.; Chen, Y.; Triller, A.; Vriz, S.; Le Saux, T.; Jullien, L.; Gautier, A. Small fluorescence-activating and absorption-shifting tag for tunable protein imaging in vivo. Proc. Natl. Acad. Sci. U.S.A. 2016, 113, 497-502.

(28) Lingam, V. S. P. R.; Vinodkumar, R.; Mukkanti, K.; Thomas, A.; Gopalan, B. A simple approach to highly functionalized benzo[b]furans from phenols and aryl iodides via aryl propargyl ethers. Tetrahedron Lett. 2008, 49, 4260-4264.

(29) Zou, H. B.; Dong, S. Y.; Zhou, C. X.; Hu, L. H.; Wu, Y. H.; Li, H. B.; Gong, J. X.; Sun, L. L.; Wu, X. M.; Bai, H.; Fan, B. T.; Hao, X. J.; Stöckigt, J.; Zhao, Y. Design, synthesis, and SAR analysis of cytotoxic sinapyl alcohol derivatives. Bioorg. Med. Chem. 2006, 14, 2060-2071.

(30) Moreau, J.; Giovanella, U.; Bombenger, J.-P.; Porzio, W.; Vohra, V.; Spadacini, L.; Di Silvestro, G.; Barba, L.; Arrighetti, G.; Destri, S.; Pasini, M.; Saba, M.; Quochi, F.; Mura, A.; Bongiovanni, G.; Fiorini, M.; Uslenghi, M.; Botta, C. Highly emissive nanostructured thin films of organic host-guests for energy conversion. ChemPhysChem 2009, $10,647-653$.
(31) Virgili, T.; Forni, A.; Cariati, E.; Pasini, D.; Botta, C. Direct evidence of torsional motion in an aggregation-induced emissive chromophore. J. Phys. Chem. C 2013, 117, 27161-27166.

(32) Fery-Forgues, S.; Veesler, S.; Fellows, W. B.; Tolbert, L. M.; Solntsev, K. M. Microcrystals with enhanced emission prepared from hydrophobic analogues of the green fluorescent protein chromophore via reprecipitation. Langmuir 2013, 29, 14718-14727.

(33) Yuan, W. Z.; Zhang, Y. Nonconventional macromolecular luminogens with aggregation-induced emission characteristics. J. Polym. Sci., Part A: Polym. Chem. 2017, 55, 560-574.

(34) Dong, J.; Solntsev, K. M.; Tolbert, L. M. Activation and tuning of green fluorescent protein chromophore emission by alkyl substituent-mediated crystal packing. J. Am. Chem. Soc. 2009, 131, 662-670.

(35) Dong, Y.; Lam, J. W. Y.; Qin, A.; Sun, J.; Liu, J.; Li, Z.; Sun, J.; Sung, H. H. Y.; Williams, I. D.; Kwok, H. S.; Tang, B. Z. Aggregationinduced and crystallization-enhanced emissions of 1,2-diphenyl-3,4bis(diphenylmethylene)-1-cyclobutene. Chem. Commun. 2007, 32553257.

(36) Botta, C.; Benedini, S.; Carlucci, L.; Forni, A.; Marinotto, D.; Nitti, A.; Pasini, D.; Righetto, S.; Cariati, E. Polymorphism-dependent aggregation induced emission of a push-pull dye and its multi-stimuli responsive behavior. J. Mater. Chem. C 2016, 4, 2979-2989.

(37) Xue, S.; Qiu, X.; Sun, Q.; Yang, W. Alkyl length effects on solidstate fluorescence and mechanochromic behavior of small organic luminophores. J. Mater. Chem. C 2016, 4, 1568-1578. 